ORIGINAL RESEARCH PAPER

\section{THE MEDIATING ROLE OF ACCREDITATION DETAILS ON SELECTION OF BUSINESS SCHOOLS BASED ON INFORMATION FROIM ONLINE RESOURCES.}

\section{Education}

KEY WORDS: online resources, accreditation details, selection of business school, placements, infrastructure, social media, and education related web portals.
Ms.Asha Mathew

\section{Dr. J. MeenaKumari}

Research Scholar (Part time)-University of Mysore, ISME (International School of Management Excellence), Research Centre, Bangalore.

Professor and Head of Research, ISME (International School of Management Excellence), Research Centre, Bangalore.

This study adopted a descriptive research design. Primary data collection was conducted through online survey instruments amongst 300 business school aspirants in India. The researcher adopted percentage analysis and a structural equation modeling approach for the analysis of data.

The purpose of this study is to explore the mediating role of accreditation status and the selection of business schools based on the information from online resources. The findings of the study confirmed that the accreditation details act as a mediating variable between online resources and the selection of business schools. The significance of all the paths confirms the partial mediation of accreditation details on a selection of business schools. It is noted that those online resources have a significant direct effect on the selection of business schools. There exists a significant positive indirect effect of accreditation details on the online resources as well.This study will add to the existing literature on the aspects influencing millennials in their selection of business schools. This study will contribute to understanding the influence of online resources and the role of accreditation and rankings in students' selection of educational institutions.

\section{INTRODUCTION}

The education industry in India has faced tremendous changes in recent decades. The economic growth of the country depends upon the quality of education received by the citizens of that country, therefore it is identified that the education is a major driver of Indian economy, which not only stimulates them to identify and grab the opportunities, rather it help them to create the opportunity for better livelihood of self, and people in the society. The higher education in India has many segments, out of that major segments are technical education, medical education, and management education. The management educations are offered by the engineering colleges, arts \& science colleges, private universities, deemed universities, state universities, central universities, stand-alone institutions, autonomous colleges, and business schools. In India, the premier institutions which offers business educations are Indian Institute of Management (IIMs) located at various cities across India. Business schools located across India also supplements and even sometime complements in providing quality business education to the students from India and abroad.

The quality of business education depends on various factors such as curriculum \& syllabi, quality of faculty, infrastructure, etc. The candidates may search for admission in business schools after their school education, under graduation, and work experience of few years. Generally, who seeks the business education in premier business schools may appear for all India level entrance examination such as Common Admission Test (CAT), Management Aptitude Test (MAT), etc. The purpose of the study is to explore the mediating role of accreditation details on selection of business schools based on information from online resources.

\section{SELECTION CRITERIA OF B-SCHOOLS}

Punj, G. N., \& Staelin, R. (1978). Educational expenses, quality, and accessibility of the institution are few of the determinants for the selection of a business school. As per the studies conducted by Chapman, R. G. (1986). Significant college attributes that influence the selection includes cost of educational expenses, academic quality, career opportunity, availability of academic and other facilities. Arbesman-Gold, T. (2016). Points out the role of rankings in the selection of business schools by students. Sharma, C., \& Bhanot, V. (2014) points out the role of institute reputation and ranking along with the placements and quality of placements plays a significant role to shortlist business schools. (Nora, 2004)
Psychosocial factors have a major influence among the students in their choice of higher educational institution.(Dao \& Thorpe, 2015) concludes that the academic quality, infrastructure, programs offered and cost factor to impact students decision to opt for an institution for higher education.(Marconi, 2013) points out the significance of accreditation and approachability as the guiding factor for students to determine the institution for higher education.

\section{ACCREDITATION AND QUALITY}

Many researchers (Yorke 1999; Kohler 2003) vouches accreditation as a measure for quality assurance in higher education. (Dill 2007; Dew 2009) established the correlation between accreditation and students' preference of higher education institution. Demand for accreditation has increased manifolds owing to the contemporary format in higher education with an increased focus on rankings and internationalization (El-Khawas, De Pietro-Jurand, and HolmNielsen 1998; Petersen 1999; Knight 2007; Yung-Chi Hou2011), (Lamico and Jensen 2003; Smith 2010) (Salmi and Saroyan 2007; Bleiklie 2011) .The current research is to study the influence of accreditation status in online platforms among management education aspirants in their selection of institute.

\section{LITERATURE REVIEW}

Gislaine \& Emerson (2018), their paper systematically reviewed the institutional role of business school accreditation agencies. Accreditation is a growing phenomenon and has begun to permeate scientific studies, most of which are quantitative, since they focus on the process of accreditation and its positive or negative effects. Only a few studies have analyzed this phenomenon from the perspective of institutional theory. As there is no consensus regarding the performance of accreditation agencies, the purpose of this paper is to identify their institutional role in the global orientation of the organizational practices, values and decisions of business schools (BS). A systematic literature review enabled us to identify scientific publications since 2002 that have used institutional theory when discussing BS accreditation agencies. An in-depth reading of these articles led us to identify the most frequent, similar and contrasting perspectives. Seven aspects were analyzed in each article: theme, research assumption, theoretical basis, method, research context, result and suggestions for future studies. The findings suggest a certain duality in the role of these agencies. If, on the one hand, they are responsible for 
providing a quality seal, on the other hand, they promote legitimacy in the field by institutionalizing international rules. By investigating the performance of these agencies as global institutional bodies, the authors extrapolated the traditional discussion on the dynamic of interaction between local actors who both influence the field and are influenced by it, a recurring theme in institutional theory.

Nitin \& Milind (2018) in their study identified the choice factors that significantly influence students in selecting bschools. In the context of higher education especially business management education in India, a noticeable trend has been the increasing competition among b-schools to attract students both locally and internationally. Competitive pressure has forced the b-schools to look for more competitive marketing strategies in order to compete for students in their respective recruitment markets. Findings of this study will be beneficial in terms of decision making and will contribute to the roles that assist the b-schools to plan and improve the choice factors for prospective students.

Stuti Sahni \& Farhat Mohsin (2017), in their research empirically investigated factors influencing student's decision in selection of a right business school. Education is the main indicator of social, cultural and economic growth of any nation. It is among the major drivers behind the strong foundation of a society. Education has always been an important source for helping the community out for their financial misery and ensuring candidate's employability. The contribution of higher education in facilitating the overall development of county is well appreciated by all countries Management is a branch of knowledge that is a unique combination of theory and application and being a professional degree, it is accepted all around the world. This research aimed at understanding the latest trend in management education with respect to student's preference. It also aimed at studying the different factors affecting the selection of best B-School. The researchers tried to discover how far, parameters like past placement and internship, total cost on the program, ranking of the collage/university/ institute, word of mouth and other promotional activities, profile of faculties and other extra-curricular activities contribute to their selection. The present study was taken up with an objective to measure student's perception on the antecedents of management institutes and to assess their selection criteria. The main objective of this study was to evaluate the impact of the above-mentioned variables on student's opinion in selecting the best management institution.

Ritika et al. (2016), in their research identified the challenges for management education in India and explain their nature, significance and interrelations using total interpretive structural modelling (TISM), an innovative version of Warfield's interpretive structural modelling (ISM). The challenges have been drawn from literature and validated by an empirical study conducted through questionnaires administered electronically and personally to 250 management graduates. TISM has been applied to 14 finalized factors. All the identified factors, except accreditation, were found to be important. Ineffective regulatory bodies and ineffective leadership emerged as the biggest roadblocks. Several significant interrelations were found which were sometimes not revealed by plain observation. Originality/value - The existing literature has discussed the challenges for management education but not their interrelations. This paper uses TISM to demonstrate the relationships between different challenges and to explain the logic behind the relationships. The results would be useful for the owners (or managers) of management institutes faced with the same challenges.

Chris Perryer \& Victor Egan (2015), in their paper discussed about Business School Accreditation in Developing
Countries: A Case in Kazakhstan. AACSB, EQUIS, and AMBA. Accreditation provides public notification that an institution or program meets benchmark standards, and reflects an institution committed to self-study, external peer review, and continuous improvement. However, from the perspective of the more than 12,000 business schools worldwide that do not, and most likely will never, meet big three imposed benchmark, accreditation is an exclusion mechanism providing comparative advantage to accredited schools. This is more than a differentiator between accredited and nonaccredited business schools it reinforces the economic great divide between developed and less developed countries, since over $90 \%$ of accredited business schools are in developed countries. Consequently, accreditation becomes a moral and ethical imperative that should sit uneasy with anyone concerned with equality and social justice. In response, the Asian Forum on Business Education (AFBE) has designed an inclusive international accreditation system that is affordable, and fosters quality improvement at institutions that may initially be some considerable distance from meeting big three standards. This paper provides insight into one such accreditation process at a business school in Kazakhstan, and demonstrates the remarkable progress that can be achieved when quality improvement, rather than mere certification, is the guiding principle.

Cheshta Sharma \&Vikas Bhano (2014), in their study explored the factors influencing selection of management school among aspirants. The growing need of market is creating demand for professionals who are something more than an engineer and have an edge over technical knowledge with managerial skills. But the engineering graduates are always confused, do they really want to go for higher studies or they should stick to their engineering profession only. "Do we need an MBA??" this is the most important question which comes in mind of every engineering student in his/her final stages of the course. In this paper we made an attempt to analyze factors influencing selection of management school among the aspirants. A Master in Business Administration opens many doors to an advanced management position and many other great career opportunities. However, is not necessary to have an MBA to have a successful career, and the process is definitely not for everyone. We concluded from our survey that there are three key influencing factor which are reputation of the institute, quality of placements and placements which contributes $68 \%$ of all the factors of selecting a Management School.

Rizwana et al. (2013), analyzed internal and external factors affecting choice of business schools by students with the changing trends business studies have become very popular amongst the students as a means of future career. Accordingly, an issue has always been at hand the students and parents both that which higher education institution be selected for the business management education. This research paper examines different factors that influence business student's behavior in selecting a business school. The research has been carried out in the vicinity of Karachi city. The researchers used both primary and secondary methods of data collection. Primary data was collected through questionnaire. The sample of 100 students was selected. Probability sampling technique was used whereby 10 students were selected form each well-known business schools of Karachi. The researcher classified different influencing factors into two main categories -- internal and internal ones and found that both internal and external factors influence business students in selecting a business school but external factors influence students more than internal factors. The outcome of the research guide the future business management students about quality and standards of various business schools as well as assist the business school in identification of the factors critical for the students.

Santiago \& Salvador (2007), in their paper argued that recent 
changes in the wider contexts of universities and business schools signal a shift in their business model instead of a mere turn in their business cycle. The paper reviews the position of those that hold a traditionalist view of the business model of business schools and comments on the extent to which such a model applies to the ever-changing conditions that are a feature of the environment of institutions of higher learning. The paper argues that the process of globalization augments the effects of five sector-specific forces on the business model of business schools. Additionally, the paper identifies some structural factors that business schools might wish to address in order to cope with changes occurring in their wider environments. In addition to structural measures, the paper proposes several specific actions that business schools may implement to maintain and/or gain competitive advantage.

Travis (2013), in their article discussed about International Accreditation of Business Schools in Emerging Markets. The globalization of the world economy has had a direct effect on higher education (Canals, 2009; Nerad, 2010). Not only have more companies and organizations from Japan, Europe, Canada and the USA penetrated into the rest of the world, but companies and organizations from the developing countries, especially the emerging markets of Brazil, Russia, India and China (the BRICs), have also become inter- nationalized and compete in global markets. Thus business schools at Institutes of Higher Education (IHEs) worldwide must provide students not only with traditional management skills but also with management skills and perspectives that are relevant to the BRICs and other more pluralistic and multicultural realities (Scott-Kennel and Salmi, 2008; Canen and Canen, 2011; Wallerstein, 2000, pp. 432 33). They must develop strategies both to offer quality education and to compete with other institutes, including strategies involving marketing (Hemsley- Brown and Oplatka, 2006), geographic diversification, and strategic international alliances (Iniguez de Onzono and Carmona, 2007).

\section{DEVELOPMENT OF CONCEPTUAL MODEL}

The researcher has developed the conceptual model of the research based on the literature survey and it is shown in figure 1 . The following hypothesis are formulated based on the below mentioned conceptual model.

$\mathrm{Hl}$ : The online resources are having significant effect on selection of business schools.

H2: The accreditation details act as a mediating variable between online resources and selection of business schools.

The above-mentioned hypothesis were tested using structural equation modeling approach.

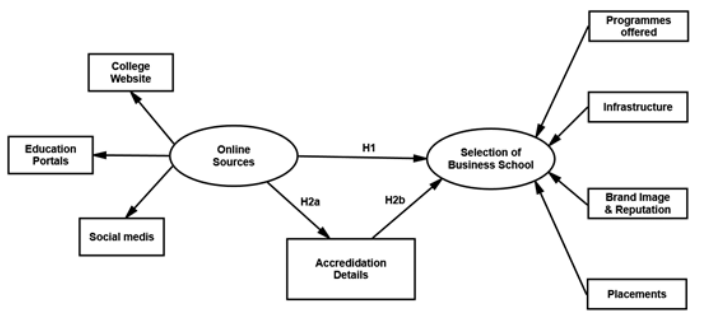

Figure 1. Conceptual Model

\section{Research Methods And Samples}

This research is designed based on descriptive research design. The primary data of the research was collected using structured google forms. The sample size of the research is 300 and the data from various parts in India. The google form survey was conducted only for the aspirants of management education. The convenience sampling method was adopted to select the samples from the target population. The primary data was analyzed through descriptive statistical tool (i.e. percentage analysis), and Structural equation modeling.

\section{RESULTS AND DISCUSSION}

Sampled Aspirants Personal Profile - Percentage Analysis

The profile of sampled aspirants of business school is presented in table 1 .

Table 1. Profile of sampled aspirants of business school

\begin{tabular}{|l|l|l|l|}
\hline S. No & Factor & Frequency & Percent \\
\hline 1 & Gender & & \\
\hline & Male & 174 & 58.00 \\
\hline & Female & 126 & 42.00 \\
\hline & Age group & & \\
\hline & Up to 18 Years & 125 & 41.67 \\
\hline & $18-23$ Years & 97 & 32.33 \\
\hline & Above 23 Years & 78 & 26.00 \\
\hline 3 & Level of Programme looking for & & \\
\hline & PG Diploma & 34 & 11.33 \\
\hline & Executive MBA & 71 & 23.67 \\
\hline & Undergraduate & 106 & 35.33 \\
\hline & Post-graduate & 89 & 29.67 \\
\hline 4 & Work experience & & \\
\hline & Fresher & 108 & 36.00 \\
\hline & Up to l year & 82 & 27.33 \\
\hline & l -3 Years & 74 & 24.67 \\
\hline & Above 3 years & 36 & 12.00 \\
\hline 5 & $\begin{array}{l}\text { Source of awareness about } \\
\text { Business School }\end{array}$ & & \\
\hline & Business School Pamphlets & 25 & 8.33 \\
\hline & $\begin{array}{l}\text { Word of mouth from Stakeholders } \\
\text { of B-School }\end{array}$ & 89 & 29.67 \\
\hline & Newspaper Advertisements & 76 & 25.33 \\
\hline & Online Sources & 110 & 36.67 \\
\hline 6 & $\begin{array}{l}\text { Preferred Online Source to } \\
\text { search information related to } \\
\text { Business School }\end{array}$ & & \\
\hline & Business School Website & 128 & 42.67 \\
\hline & Education related web portals & 94 & 31.33 \\
\hline & Social media & 78 & 26.00 \\
\hline 7 & $\begin{array}{l}\text { Priority given to select Business } \\
\text { School }\end{array}$ & & \\
\hline & Brand Image and Reputation & 74 & 24.67 \\
\hline & Infrastructure & 23 & 7.67 \\
\hline & Placements & 64 & 21.33 \\
\hline & Accreditation & 32 & 10.67 \\
\hline & Word of Mouth recommendation & 49 & 16.33 \\
\hline & Quality of Faculty & 19 & 6.33 \\
\hline & Course and Electives & 9.00 \\
\hline & Others & 12 & 100.00 \\
\hline & Total & & \\
\hline
\end{tabular}

The mediating role of accreditation details on selection of business schools based on information from online resources - Structural Equation Modeling (SEM) approach

The conceptual model of the research was drawn in IBM AMOS 20.0 and connected with data file created in IBM SPSS 20.0 statistical software. The figure 2 shows the SEM model of the research with unstandardized regression coefficients, and figure 3 represents SEM model with standardized regression coefficients. The research adopted second order SEM model for the analysis, in which the average score of the items are loaded as scores for the factors.

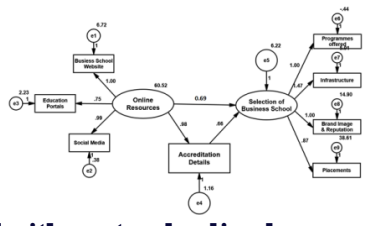

Figure 2. SEIM with unstandardized regression coefficients 


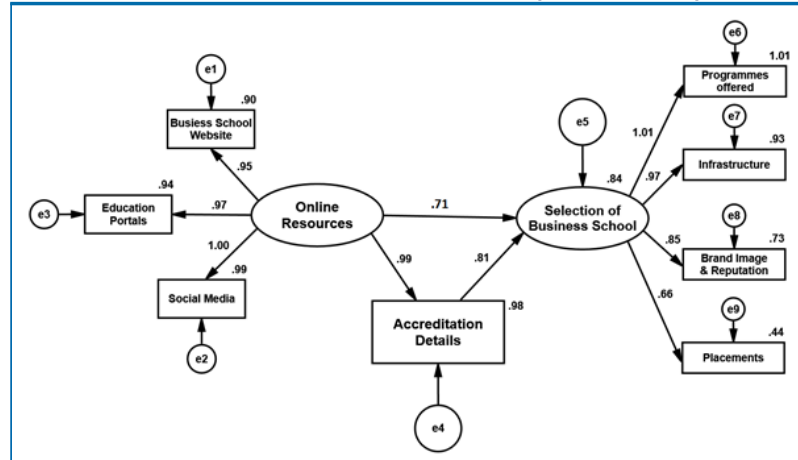

Figure 3. SEM with standardized regression coefficients

The figure 2 and 3 shown above clearly indicates that all the factors of online resources such as business school websites, education portals, and social media are having significant correlation (i.e. factor loading) with its main construct with the coefficient of more than 0.5. Similarly, the factors (i.e. programmes offered, infrastructure, brand image \& reputation, and placements) of selection of business school construct also has significant factor loading with its main construct. The regression estimates between the main constructs of the SEM model are summarized in table 2.

Table 2. Regression Estimates of the SEMI

\begin{tabular}{|c|c|c|c|c|c|c|c|c|}
\hline \multicolumn{3}{|c|}{ Path } & \multirow{2}{*}{\begin{tabular}{|c|}
$\begin{array}{c}\text { Unsta } \\
\text { ndard } \\
\text { ized } \\
\text { Coeffi } \\
\text { cient }\end{array}$ \\
0.689 \\
\end{tabular}} & \multirow{2}{*}{\begin{tabular}{|l|} 
S.E. \\
\\
0.1 \\
57 \\
\end{tabular}} & \multirow{2}{*}{\begin{tabular}{|c|}
$\begin{array}{c}\text { Standa } \\
\text { rdized } \\
\text { Coeffi } \\
\text { cient }\end{array}$ \\
0.711 \\
\end{tabular}} & \multirow{2}{*}{\begin{tabular}{|l|} 
C.R. \\
\\
0.56 \\
9
\end{tabular}} & \multirow{2}{*}{\begin{tabular}{|l|}
\multicolumn{1}{|c}{$\mathbf{P}$} \\
\\
$<0.00$ \\
$1 * *$
\end{tabular}} & \multirow{2}{*}{\begin{tabular}{|c|}
$\begin{array}{c}\text { Hypot } \\
\text { hesis } \\
\text { result }\end{array}$ \\
$\begin{array}{c}\mathrm{Hl} \text { is } \\
\text { Signifi } \\
\text { cant }\end{array}$ \\
\end{tabular}} \\
\hline $\begin{array}{l}\text { Selection } \\
\text { of Business } \\
\text { School }\end{array}$ & \begin{tabular}{|l|}
- \\
-
\end{tabular} & $\begin{array}{c}\text { Online } \\
\text { Resour } \\
\text { ces }\end{array}$ & & & & & & \\
\hline $\begin{array}{l}\text { Accreditati } \\
\text { on Details }\end{array}$ & $\begin{array}{c}<-- \\
-\end{array}$ & $\begin{array}{c}\text { Online } \\
\text { Resour } \\
\text { ces }\end{array}$ & 0.979 & $\begin{array}{l}0.0 \\
21\end{array}$ & 0.990 & $\begin{array}{c}47.5 \\
47\end{array}$ & $\begin{array}{l}<0.00 \\
1 * *\end{array}$ & \begin{tabular}{|c|} 
H2a is \\
Signifi \\
cant
\end{tabular} \\
\hline \begin{tabular}{|c} 
Selection \\
of Business \\
School
\end{tabular} & $\begin{array}{l}<- \\
-\end{array}$ & $\begin{array}{l}\text { Accred } \\
\text { itation } \\
\text { Details }\end{array}$ & 0.657 & $\begin{array}{l}0.1 \\
58\end{array}$ & 0.807 & $\begin{array}{c}4.16 \\
1\end{array}$ & $\begin{array}{l}<0.00 \\
1 * *\end{array}$ & $\begin{array}{c}\text { H2b is } \\
\text { Signifi } \\
\text { cant }\end{array}$ \\
\hline
\end{tabular}

The standardized regression coefficient of online resources on selection of business school is 0.711 which is positive and significant at $1 \%$ level. It is also indicating that $\mathrm{Hl}$ hypothesis is significant, therefore it is concluded that the online resources is having significant effect on selection of business schools. Similarly, the standardized regression coefficient of online resources on accreditation details is 0.990 which is positive and significant at $1 \%$ level. The standardized regression coefficient of accreditation details on selection of business school is 0.807 , which is positive and significant at $1 \%$ level.

The results of the SEM also indicate that the conceptual model depicted in the SEM is having perfect fit with the data gathered through the research survey. All the model fitness indices of the above-mentioned SEM fall under the recommended range.

Table 3. The direct, indirect, and total effect between constructs

\begin{tabular}{|c|c|c|c|c|c|c|c|c|c|}
\hline \multirow[t]{2}{*}{ Factors } & \multicolumn{3}{|c|}{ Direct effect } & \multicolumn{3}{|c|}{ Indirect Effect } & \multicolumn{3}{|c|}{ Total effect } \\
\hline & 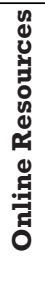 & 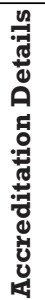 & 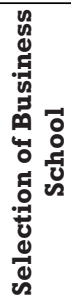 & 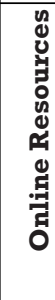 & 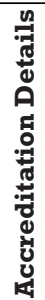 & 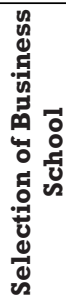 & 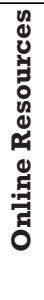 & 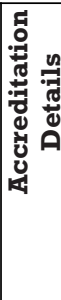 & 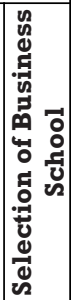 \\
\hline
\end{tabular}

\begin{tabular}{|c|c|c|c|c|c|c|c|c|c|}
\hline Accreditatio & 0.99 & 0.00 & 0.00 & 0.00 & 0.00 & 0.000 & 0.99 & 0.00 & 0.00 \\
n Details & 0 & 0 & 0 & 0 & 0 & & 0 & 0 & 0 \\
\hline Selection of & 0.71 & 0.80 & .000 & 0.79 & 0.00 & 0.000 & 1.51 & 0.80 & 0.00 \\
Business & 1 & 7 & & 9 & 0 & & 0 & 7 & 0 \\
School & & & & & & & & & \\
\hline
\end{tabular}

The direct, indirect, and total effect between constructs are tabulated in the table 3 .

that $\mathrm{H} 2$ hypothesis is significant ( $\mathrm{H} 2 \mathrm{a}$ and $\mathrm{H} 2 \mathrm{~b}$ both are significant), therefore it is concluded that the accreditation details acting as a mediating variable between online resources and selection of business schools. Since the paths $\mathrm{H} 1, \mathrm{H} 2 \mathrm{a}$, and $\mathrm{H} 2 \mathrm{~b}$ all are significant, which confirms the partial mediation of accreditation details on selection of business school, because the online resources is also having significant direct effect on selection of business school, and the online resources through accreditation details (i.e. indirect effect ) also has significant positive effect on selection of business school.

\section{CONCLUSION}

The young generation are willing to source most of the information required for their decision-making from online resources rather than traditional resources, as the information retrieval from online resources requires minimum time, cost, and effort. The selection of business school for management education is an important career decision for the aspirants of the business school, so they would like to source the relevant information from all resources (predominantly from online resources) to identify the schools, eligibility criteria, application and selection process of the business school. Similarly, the business schools are relying on accreditation process for building brand image, demonstrate their quality standards and attract meritorious students. B Schools prefer to undergo the accreditation process of NBA, NAAC, and other international accreditation agencies to assure quality. The findings of the study proved that the accreditation details of the business schools act as the mediating variable and boost the selection of the business school while compared to direct effect of online resources on selection of business schools.

\section{REFERENCES}

1. Arbesman-Gold, T. (2016). How do you choose? How rankings and other factors influence MBA program choice at elite business schools. (Doctoral dissertation, New York University).

2. Balaji.S.,\& Mudholkar (2012). A study student's choice factors for selecting bschools with special reference to Mumbai. International Journal of Multidisciplinary Research,Vol.2, Issue 4, pp. 88-95.

3. Bleiklie, I. 2011. "Excellence, Quality and the Diversity of Higher Education Systems." In Questioning Excellence in Higher Education: Policies, Experiences and Challenges in National and Comparative Perspective, edited by Michelle Rostan and

4. MassimilianoVaira,21-35.Rotterdam:Sense.

5. Chapman, R. G. (1986). Toward a theory of college selection: A model of college search and choice behavior. ACR North American Advances.

6. Cheshta Sharma \& Vikas Bhano(2014). Exploratory research on the factors influencing selection of management school among aspirants. International Journal of Management Research \& Review, Volume 4, Issue 10, No-2,pp: 961 980.

7. Chris Perryer \& Victor Egan(2015). Business School Accreditation in Developing Countries: A Case in Kazakhstan, Journal of Eastern European and Central Asian Research,Vol 2,No 2,pp: 1-11.

8. Dao, M.T.N., \& Thorpe, A. (2015).What factors influence Vietnamese students' choice of university? International Journal of Educational Management, 29(5), 666-681.https://doi.org/10.1108/IJEM-08-2014-0110

9. Dew, J. 2009. "Quality Issues in Higher Education." The Journal of Quality \& Participation 32 (1):4-9.

10. Dill, D. D. 2007. Quality Assurance in Higher Education: Practices and Issues. The 3rd International Encyclopedia of Education, 1-13.

11. El-Khawas, E., R. De Pietro-Jurand, and L. Holm-Nielsen. 1998. Quality Assurance in Higher Education: Recent Progress: Challenges Ahead. Washington, D.C: Human Development Network, Education, World Bank. www.worldbank.org/education/tertiary/quality.html.

12. Gislaine Cristina dos Santos Teixeira \& Emerson Antonio Maccari (2018). The institutional role of business school accreditation agencies: a systematic literature review. Revista de Gestão,Vol. 25 Issue:3,pp.274-290.

13. Kohler, J. (2003). Quality Assurance, Accreditation, and Recognition of Qualifications as Regulatory Mechanisms in the European Higher Education Area. Higher Education in Europe 28 (3):317-30.

14. Knight, J. 2007. "Cross-border Higher Education: Issues and Implications for Quality Assurance and Accreditation." In GUNI Series on the Social Commitment of Universities 2: Higher Education in the World (2007), Accreditation for Quality Assurance-What is at Stake?, 134-46. New York, NY: 
Palgrave/MacMillan

15. Lamico, H., and H. T. Jensen. 2003. "On Accreditation Schemes for Higher Education in Europe."'European Education 35 (2):5-17.

16. Nitin G Zadpeand \& Milind S Pande (2018). A Study of Choice Factors for Selecting B-Schools, International Journal of Latest Technology in Engineering, Management \& Applied Science (IJLTEMAS), Volume VII, Issue IV,pp:235-237.

17. Marconi, G. (2013), Rankings, accreditations, and international exchange students. IZA Journal of European Labor Studies, 2(1), 5. https://doi.org/ $10.1186 / 2193-9012-2-5$

18. Nora, A. (2004). The Role of Habitus and Cultural Capital in Choosing a College, Transitioning From High School to Higher Education, and Persisting in College Among Minority and Nonminority Students. Journal of Hispanic Higher Education, 3(2), 180-208. https://doi.org/ 10.1177/ 15381927042 63189

19. Petersen, J. C. 1999. Internationalizing Quality Assurance in Higher Education. Washington, D.C.: Council for Higher Education Accreditation (CHEA)

20. Punj, G. N., \& Staelin, R. (1978). The Choice Process for Graduate Business Schools. Journal of Marketing Research, 15(4), 588-598. https://doi.org/ 10.1177/002224377801500408

21. Ritika Mahajan, Rajat Agrawal, Vinay Sharma, \& Vinay Nangia, (2016). Analysis of challenges for management education in India using total interpretive structural modelling. Quality Assurance in Education, Vol. 24, Issue. 1, pp.95-122.

22. Rizwana Bashir, Atif Hassan, Muhammad Ali Pasha and Shoaib Ahmed (2013), Analysis of Internal \& External Factors Affecting Choice of Business Schools by Students, Journal of Management and Social Sciences, Vol. 9, No. 2, pp. 3141.

23. Santiago Iñiguez de Onzoño, Salvador Carmona, (2007). The changing business model of B- schools. Journal of Management Development, Vol. 26 Issue: 1, pp.22-32.

24. Salmi, J., and A. Saroyan. 2007. "League Tables as Policy Instruments: The Political Economy of Accountability in Tertiary Education." In GUNI Series on the Social Commitment of Universities 2: Higher Education in the World (2007),Accreditation for Quality Assurance - What is at Stake?, 79-95. New York,NY:Palgrave/MacMillan

25. Sharma, C., \& Bhanot, V. (2014). Exploratory Research On The Factors Influencing Selection Of Management School Among Aspirants. IJMRR, Volume 4(Issue 10), 961-980. http://ijmrr.com/admin/ upload_data/journal Cheshta\%20Sharma\%20\%2020ct\%2014mrr.pdf

26. Stuti Sahni, \& Farhat Mohsin (2017). Factors influencing student's decision in selection of a right business school - an empirical investigation. International Education \& Research Journal,Vol.3, Issue. 7, pp. 16-18.

27. Travis E.F. (2013). International Accreditation of Business Schools in Emerging Markets: A Study of FGV-EAESP and Insper in Brazil. In: Alon I., Jones V., McIntyre J.R. (eds) Innovation in Business Education in Emerging Markets. Palgrave Macmillan, London.

28. Yorke, M. (1999). Assuring Quality and Standards in Globalised Higher Education. Quality Assurance in Education 7 (1): 14-24.

29. Yung-Chi Hou, A. 2011. "Quality Assurance at a Distance: International Accreditation in Taiwan Higher Education." Higher Education 61 (2): 179-91. 